\title{
Size-dependence of volatile and semi-volatile organic carbon content in phytoplankton cells
}

\author{
Sergio Ruiz-Halpern ${ }^{1,2 *}$, Pedro Echeveste ${ }^{1,3}$, Susana Agustí ${ }^{1,4}$ and Carlos M. Duarte ${ }^{1,4}$ \\ 1 Department of Global Change Research, Instituto Mediterráneo de Estudios Avanzados, Consejo Superior de Investigaciones Cientificas-Universitat de les Illes \\ Balears, Esporles, Illes Balears, Spain \\ ${ }^{2}$ Centre for Coastal Biogeochemistry Research, School of Environment, Science and Engineering, Southern Cross University, Lismore, NSW, Australia \\ ${ }^{3}$ Laboratório de Biotecnologia de Algas, Departamento de Botânica, Universidade Federal de São Carlos, São Carlos, Brazil \\ ${ }^{4}$ School of Plant Biology, The UWA Oceans Institute, The University of Western Australia, Crawley, WA, Australia
}

Edited by:

Claire Mahaffey, University of

Liverpool, UK

\section{Reviewed by:}

Christian Lonborg, Australian

Institute of Marine Science,

Australia

Jia-Jang Hung, National Sun Yat-sen

University, Taiwan

\section{${ }^{*}$ Correspondence:}

Sergio Ruiz-Halpern, Centre for

Coastal Biogeochemistry Research,

School of Environment, Science and

Engineering, Southern Cross

University, 1 Military Road, Lismore,

NSW 2480, Australia

e-mail:shalpern@scu.edu.au
The content of volatile and semivolatile organic compounds (VOC and SOC), measured as exchangeable dissolved organic carbon (EDOC), was quantified in 9 phytoplanktonic species that spanned 4 orders of magnitude in cell volume, by disrupting the cells and quantifying the gaseous organic carbon released. EDOC content varied 4 orders of magnitude, from 0.0015 to $14.12 \mathrm{pg} \mathrm{C}$ cell $^{-1}$ in the species studied and increased linearly with increasing phytoplankton cell volume following the equation EDOC (pg

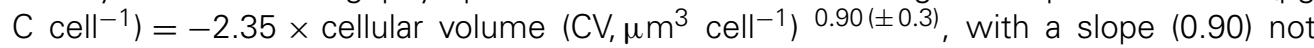
different from 1 indicating a constant increase in volatile carbon as the cell size of phytoplankton increased. The percentage of EDOC relative to total cellular carbon was small but varied 20 fold from 0.28 to $5.17 \%$, and no obvious taxonomic pattern in the content of EDOC was appreciable for the species tested. The cell release rate of EDOC is small compared to the amount of carbon in the cell and difficult to capture. Nonetheless, the results point to a potentialf flux of volatile and semivolatile phytoplankton-derived organic carbon to the atmosphere that has been largely underestimated and deserves further attention in the future.

\section{Keywords: phytoplankton, organic carbon, climate change, biogeochemistry, allometric}

\section{INTRODUCTION}

Recent methodological developments have enabled the measurement of the gaseous fraction of organic carbon dissolved in seawater, referred to as exchangeable dissolved organic carbon (EDOC). EDOC contains a numerous and largely unknown mixture of volatile (VOC) and semivolatile (SOC) organic carbon compounds (Park et al., 2013). This bulk measurement has drawn the attention to the role of this important, but largely overlooked, pool of carbon in marine ecosystems (Dachs et al., 2005; RuizHalpern et al., 2010). Thus far, measurements refer to EDOC concentrations and air-sea exchange, and the loads of volatile and semivolatile compounds in marine organisms remain poorly explored.

The volatile and semivolatile organic compounds found in macroalgae and microalgae (Laturnus, 2001; Colomb et al., 2008) can be an important source of these compounds to the ecosystem (Gschwend et al., 1985; Bravo-Linares et al., 2010; Ruiz-Halpern et al., 2010). Hence, the release of VOC and SOC by marine autotrophs can support significant fluxes to the atmosphere (Sinha et al., 2007), with potentially important photochemical and climatic effects (Williams, 2004). Indeed, some of the compounds released by phytoplankton, such as dimethyl sulfide (DMS), are of global relevance, (Van Alstyne, 2008). However, knowledge of VOC and SOC content of marine autotrophs is limited to specific compounds released by marine primary producers (e.g., organohalogens, isoprenes, alcohols, and DMS) (Giese et al., 1999; Sinha et al., 2007). Thus, the total pool of EDOC contained in marine primary producers has not been reported as such yet.

The organic carbon content of phytoplankton has been demonstrated in several studies to be closely scaled to cell size, conducive to the development of allometric scaling relationships to predict cellular carbon content from cell size (e.g., Strathmann, 1967; Verity et al., 1992; Menden-Deuer and Lessard, 2000). These allometric relationships have proven useful to calculate carbon-based biomass from estimates of phytoplankton size and abundance, as well as the carbon flow from phytoplankton of various cell sizes to consumers (Kiørboe, 1993). However, these scaling laws are based on the assumed total pool since VOC and SOC were not considered in the particulate organic carbon (POC) values used, mostly estimated from dried filtered samples, which do not include VOC and SOC. Yet, reports of size-dependent release of DMS (Keller, 1988) suggest that similar allometric relationships may exist for the cellular content of VOC and SOC in marine microautotrophs.

Here we report the EDOC content of phytoplankton cells and test its hypothesized size-dependence. We do so for nine marine phytoplankton species, from different taxonomic groups. We then assessed the variability in EDOC content with phytoplankton cell size.

\section{MATERIALS AND METHODS}

Estimates of cell size and EDOC concentration were measured nine phytoplankton species (Table 1) available in cultures that 
Table 1 | Cell volume, cell carbon content calculated using the equations from Verity et al. (1992), exchangeable cellular organic carbon content (EDOC), percentage of cellular C comprised by EDOC, percentage of cells ruptured by the mechanical procedure applied, and cellular carbon content derived from a compilation of previous studies that estimate carbon content from cell volume.

\begin{tabular}{|c|c|c|c|c|c|c|c|c|c|c|c|}
\hline \multirow{2}{*}{$\begin{array}{l}\text { Species } \\
\text { Units }\end{array}$} & \multicolumn{2}{|c|}{ Cell volume } & \multicolumn{2}{|c|}{ Carbon } & \multicolumn{2}{|c|}{ EDOC } & \multirow{2}{*}{$\frac{\text { EDOC }}{\% \text { of cell } \mathrm{C}}$} & \multicolumn{2}{|c|}{ Disrupted cells } & \multirow{2}{*}{$\frac{\text { Reported C }}{\text { pg C cell-1 }}$} & \multirow[t]{2}{*}{ Source } \\
\hline & $\mu \mathrm{m}^{3}$ & SE & pg C cell ${ }^{-1}$ & SE & pg C cell-1 & SE & & $\%$ of total & SE & & \\
\hline Prochlorococcus marina & 0.064 & 0.01 & 0.041 & 0.008 & 0.0022 & 0.001 & 5.17 & 43.6 & 5.6 & & \\
\hline Synechococcus sp. & 0.69 & 0.26 & 0.314 & 0.13 & 0.0015 & 0.001 & 0.48 & 33.7 & 3.2 & 0.6 & Verity et al., 1992 \\
\hline Micromonas pusilla & 11.7 & 0.2 & 3.617 & 0.11 & 0.033 & 0.02 & 0.91 & 31.7 & 6.2 & 0.8 & $\begin{array}{l}\text { Montagnes et al., } \\
1994\end{array}$ \\
\hline Phaeodactylum tricornutum & 69 & 2.2 & 16.73 & 0.85 & 0.11 & 0.05 & 0.67 & 68.2 & 9.2 & 9 & Strathmann, 1967 \\
\hline Dunaliella sp. & 157.6 & 3.5 & 34.12 & 1.27 & 0.1 & 0.12 & 0.28 & 46.3 & 6.8 & $41.7-52$ & Mullin et al., 1966 \\
\hline Phaeocystis sp. & 515.6 & 11.5 & 94.89 & 3.56 & 2.9 & 1.14 & 2.97 & 43.5 & 16.6 & & $\begin{array}{l}\text { Montagnes et al., } \\
1994\end{array}$ \\
\hline Amphidinium carterae & 1465.9 & 17.4 & 233.8 & 5.09 & 0.55 & 0.49 & 0.23 & 31 & 3.8 & $95-259$ & $\begin{array}{l}\text { Menden-Deuer } \\
\text { and Lessard, } 2000\end{array}$ \\
\hline Melosira nummuloides & 1954.4 & 13.14 & 299.7 & 3.99 & 14.1 & 11.27 & 4.51 & 20.8 & 13.2 & & \\
\hline Thalassiosira sp. & 2380.6 & 39.3 & 355.3 & 10.29 & 11.8 & 4.66 & 3.22 & 11.6 & 4.2 & 316 & Strathmann, 1967 \\
\hline
\end{tabular}

spanned a broad size-spectrum. Additional species e.g., Chlorella marina (Butcher, 1952), Navicula sp. (Bory de Saint-Vincent, 1822) and Heterocapsa sp. (Stein, 1883) were tested but results could not be obtained because the cells could not be lysed by the mechanical method used, and chemical methods can affect EDOC estimates (see discussion for details). The cultures were grown in triplicate $1 \mathrm{~L}$ bottles under optimal temperature conditions at $18^{\circ} \mathrm{C}$ for most species, $21^{\circ} \mathrm{C}$ for Synechococcus sp. (Nageli, 1849) and Prochlorococcus marina (Chisholm et al., 1992) and $5^{\circ} \mathrm{C}$ for Melosira nummuloides (Agardh, 1824), and under continuous light conditions, in a nutrient-rich F/2 medium (Guillard and Ryther, 1962), except for Prochlorococcus marina, which grew in Pro-99 medium modified from Chisholm et al. (1992), and Melosira nummuloides, which grew in $\mathrm{L} 1+\mathrm{Si}$ medium following Guillard and Hargraves (1993). The duration of the experiments varied among the different species depending on population growth rates, as the measurements were performed at the onset of the stationary phase, when species reached their maximum expected cell abundance. Measurements of cell abundance were carried out every 2-3 days until no appreciable change in abundance was recorded. These species were chosen because they encompass a wide variety of taxonomic lineages, and span several orders of magnitude in cell size.

Cultures were sampled daily or every 2 days to follow changes in cell abundance. Changes in the abundance of cells for all species, except Melosira nummuloides, were quantified on fresh duplicate $1 \mathrm{ml}$ samples counted in a FACSCalibur Flow Cytometer (Becton Dickinson). An aliquot of a calibrated solution of $1 \mu \mathrm{m}$ diameter fluorescent beads (Polysciences Inc.) was added to the samples as an internal standard for the quantification of cell concentration. The red, green and orange fluorescence, and forward and side scattering signals of the cells and beads were used to detect different populations and to differentiate them from the fluorescent beads (Marie et al., 2000). Because Melosira nummuloides forms aggregates of cells, flow cytometry is not a reliable method to properly quantify cell abundance. Thus, changes in the abundance of cells were quantified by using 3.2- $\mu \mathrm{L}$ Fuchs-Rosenthal counting chambers (catalog No. 3720, Hausser Scientific, Horsham, PA) and counted under a light microscope at 100 magnifications (Zeiss Axioplan 2 Imaging transmitted light microscope).

The cell volume of the different species was calculated by approximation to the nearest simple geometric shape (Hillebrand et al., 1999), from the dimensions of ca. 25 cells for each species measured at $\times 1000$ under a Zeiss Axioplan 2 Imaging transmitted light microscope. The cell diameter of Prochlorococcus marina was estimated in samples analyzed by scanning electron microscopy (SEM, HITACHI S-3400N).

Extraction of EDOC followed immediately once the onset of the stationary phase was reached. Two replicate $400 \mathrm{~mL}$ acidcleaned bottles were filled from each triplicate culture bottle. One was immediately processed for EDOC, and used as a blank to measure EDOC concentrations in the culture medium prior to lysing the cells. The second one received $17 \mathrm{~g}$ of $0.5 \mathrm{~mm}$ glass beads and $16 \mathrm{~g}$ of $0.1 \mathrm{~mm}$ glass beads, and was subject to intense vibration for $20 \mathrm{~min}$ on a high speed (3200 r.p.m) vortex to mechanically lyse the cells. The use of chemicals to lyse cells, such as sodium dodecyl sulfate (SDS) was found to also interfere in the measurement of EDOC. Cell abundance was counted again following this procedure so that the percentage of cells lysed (Table 1) was calculated from the ratio between the cell abundance measured before and after the vortexing procedure. Immediately after vortexing the sample, EDOC was measured following the procedure described in Ruiz-Halpern et al. (2010). Briefly, each $400 \mathrm{~mL}$ bottle was bubbled with a stream of High purity $\mathrm{N}_{2}$ gas, with a flow rate of $500-600 \mathrm{~mL} \mathrm{~min}^{-1}$, for $8 \mathrm{~min}$, determined to suffice to reach equilibrium. The gas evolved from the cultures, containing EDOC, was equilibrated in $50 \mathrm{~mL}$ of an acidified $\left(\mathrm{H}_{3} \mathrm{PO}_{4}\right)$ ultra-pure (free of carbon) water trap, to a $\mathrm{pH}$ of 2-3. This water was immediately transferred to $10 \mathrm{~mL}$ precombusted $\left(4.5 \mathrm{~h}, 450^{\circ} \mathrm{C}\right)$ glass ampoules and sealed under flame. EDOC was measured in duplicate, for each triplicate bottle, on 
a Shimadzu TOC-Vcsh (total organic carbon) analyser, with the sparge gas turned off (Spyres et al., 2000). Certified reference materials (CRMs) of $2 \mu \mathrm{mol} \mathrm{L}^{-1}$ (Low carbon water, LCW) and $44 \mu \mathrm{mol} \mathrm{L}^{-1}$ (Deep seawater reference, DSR, provided by D.A Hansell and W. Chen from the University of Miami) were analyzed concurrently with the samples to assess the accuracy of our estimates. LCW was used to remove the instrument's blank and accuracy for the DSR was better than $\pm 4 \mu \mathrm{mol}$.

The EDOC released by the lysed cells was calculated as the difference between EDOC in untreated $v$ lysed cultures. The EDOC content (pg Cell ${ }^{-1}$ ) of each species was calculated from the ratio between the EDOC released (pmol $\mathrm{C} \mathrm{L}^{-1}$ ) and the concentration (cell $\mathrm{L}^{-1}$ ) of cells lysed by the mechanical treatment, calculated as the difference in cell concentration before and after the mechanical treatment. The cell carbon content of the cultures was calculated using the relationship given in Verity et al. (1992), between cell volume $\left(\mu \mathrm{m}^{3}\right)$ and carbon mass (pg Cell $\left.{ }^{-1}\right)$ with the form $0.433(\mathrm{CV})^{0.863}$ (Verity et al., 1992), where $\mathrm{C}$ is the cellular carbon content, and CV is the measured cell volume.

\section{RESULTS}

The percentage of cells lysed by the mechanical treatment in the phytoplankton cultures was $37 \pm 6 \%$ SE (calculated from Table 1). Phaeodactylum sp. (Bohlin, 1897) cells were the most vulnerable ( $68 \%$ cells lysed), while Thalassiosira sp. (Cleve, 1873) had the lowest percentage of cells lysed (11\% cells lysed, Table 1). The carbon content from cell volume using the equations in Verity et al. (1992) were within the same order of magnitude as values previously reported for the same phytoplankton species (Table 1).

The cellular EDOC content varied almost four orders of magnitude across species, from 0.0015 to $14.12 \mathrm{pg} \mathrm{C}$ cell-1 (Table 1), and increased closely with cell size (Figure 1), as described by the orthogonal fit.

$$
\begin{aligned}
& \operatorname{EDOC}\left(\operatorname{pg~C} \text { cell }^{-1}\right)=- \\
& \left(\mathrm{CV}, \mu \mathrm{m}^{3} \text { cell }^{-1}\right)^{0.90( \pm 0.3)} \\
& \left(R^{2}=0.86, p<0.05, n=9\right)
\end{aligned}
$$

where the slope was not significantly different from 1 ( $t$-test, $P>0.05)$, indicating that the EDOC concentration, per unit cell volume, was independent of cell size. EDOC represented, on average $( \pm$ SE) $2.04 \pm 0.21 \%$ of the carbon content of phytoplankton cells (Table 1), but ranged greatly across species, from $0.28 \%$ of the carbon content of Dunalliela $s p$, the species with the lowest EDOC concentration to $5.17 \%$ of the carbon content of Prochlorococcus marina, the species with the highest EDOC concentration (Table $\mathbf{1}$ ).

\section{DISCUSSION}

We provide here the first estimate of the EDOC content of phytoplankton cells, and assess the fraction of cell carbon represented by EDOC. After careful consideration of the different options to disrupt the cell membranes of healthy cells mechanical: vortexing, sonication, chemical: detergents such as sodium dodecyl sulfate (SDS) and following tests with alternative methods

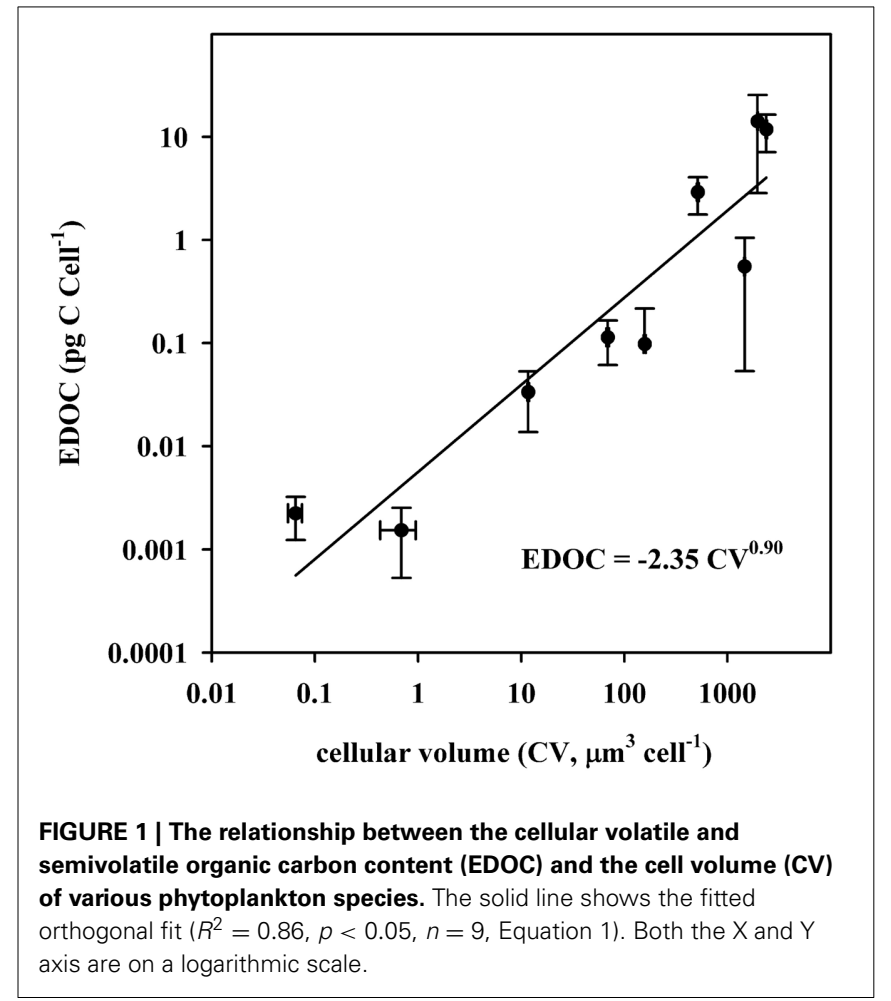

(e.g., sonication and SDS), mechanical disruption of the cells was chosen as the method that most effectively lysed cells while avoiding impacts on EDOC. Chemical treatments were found to be inadequate for 2 reasons: (1) they add carbon and as a foaming surfactant could, potentially, contaminate our samples during EDOC extraction, and (2) are very aggressive denaturing agents, possibly affecting the volatility of some compounds. Sonication has previously been used to disrupt cells in yeasts (Borthwick et al., 2005), but the intense ultrasound waves at which the sample is exposed heats the sample and by cavitation, removes a significant amount of the gases dissolved from the medium (Butler et al., 1994), rendering this approach invalid for the purpose of measuring the EDOC pool after disruption of the cells.

Vortexing the sample was the most appropriate method to obtain EDOC form the cells. However, there are at least two drawbacks that warrant consideration. Firstly, the turbulence created to disrupt the cells may facilitate the escape of some of the EDOC released during cell disruption, as a small headspace is left in the bottle, so that appropriate turbulence and cell-bead friction can be facilitated. Hence, the EDOC measurements provided here should be considered conservative estimates. Secondly, it is not universal, and not all phytoplankton species are disrupted by this method. A small species (Chlorella sp.) as well as the two larger species tested (Heterocapsa sp. and Navicula sp.) yielded virtually no cell breakage after the vortexing treatment, thus, no EDOC release could be calculated. The size differences between the species where vortexing failed, and the variability in the disruption percentage, suggests that other factors relative to the particular characteristics of each individual species affect the efficiency of the vortexing procedure in lysing the cells. 
The results presented demonstrate that phytoplankton contain a small, yet quantifiable amount of EDOC that increases linearly with increasing cell size. EDOC was independent of cell size, varying 20 -fold across the species tested. The percent cellular $\mathrm{C}$ comprised by EDOC averaged 2.04\%, however, these percentages should only be taken as first order estimations as two different methods were used to calculated carbon content. Examination of the variability in the percent cellular $\mathrm{C}$ comprised by EDOC across species did not reveal any obvious phylogenetic pattern, as similarly high \% EDOC values (5.17 to $4.51 \%$ ) were observed for a cyanobacteria (Prochlorococcus marina), a diatom (Melosira nummuloides) and a Prymnesiophyte [Phaeocystis sp. (Lagerheim, 1896), Table 1], whereas similarly low values $(0.48-0.23 \%)$ were observed for a dinoflagellate (Amphidinium carterae), a chlorophyte [Dunaliella sp. (Teodoresco, 1905)], and a cyanobacteria (Synechococcus sp., Table 1).

Cell lysis is particularly important in the oligotrophic ocean (Agustí et al., 1998), and can happen by several mechanisms including cell death, viral infection and zooplankton grazing (Jackson, 1980; Fuhrman, 1999; Strom et al., 1997; Moller, 2005). This leads to the release of the cellular contents of phytoplankton, delivering volatile and semi-volatile organic compounds. EDOC, which is likely to be composed of low molecular weight compounds, may also transfer through cellular membranes, through gradient driven simple diffusion. Whereas the non-volatile forms of DOC will either be used by bacteria or accumulate in the water column (Strom et al., 1997; Ruiz-Halpern et al., 2011), the volatile and semi-volatile EDOC forms can also be ventilated, depending on the equilibrium concentrations between the atmosphere and the water surface.

The few published reports suggest a prevalence of a net flux (Dachs et al., 2005; Ruiz-Halpern et al., 2010), or balance (RuizHalpern et al., 2014) of total volatile and semi-volatile organic carbon from the atmosphere to the ocean. The ocean is, however, a net source of some key volatile compounds, such as DMS, isoprene and halogenated compounds, to the atmosphere (Laturnus, 2001; Sinha et al., 2007). Thus, a large portion of the EDOC measured in ambient water, or the atmosphere, may have a phytoplanktonic origin. Indeed, cell lysis (induced by cell death, viral infection or grazing) is expected to be a source of volatile and semi-volatile compounds that are specifically produced by marine organisms, such as DMS or cyanobacterial toxins (Dembitsky et al., 2000), to the atmosphere, while the ocean will receive compounds which are produced by human activity (such as POPs) or are specific of the terrestrial biome (e.g., terpenoids).

Our results suggest that changes in community structure may affect volatile and semi-volatile carbon release from phytoplankton. Indeed, release rates will depend on community structure, cell lysis rates and other potential factors (e.g., nutrient availability). These properties are not, however, independent, as some of the species with high volatile and semi-volatile carbon content, such as Prochlorococcus marina, dominate the oligotrophic ocean where high phytoplankton lysis rates have been reported (Agustí et al., 1998, 2001). Moreover, mortality rates of phototrophs increase with decreasing cell size (Marbà et al., 2007) suggesting also a major contribution to EDOC release when picophytoplankton communities dominate the water column.
Picophytoplankton, and in particular, Prochlorococcus sp, are particularly sensitive to stressors such as high UV radiation (Llabrés and Agustí, 2006) or pollutants (Echeveste et al., 2010) that induce high mortality on oceanic Prochlorococcus sps. and pico-phytoplankton in general.

The forecasted future warming scenario could potentially benefit the smaller size spectrum of the phytoplankton communities such as Prochlorococcus (Agawin et al., 2000; Moran et al., 2010). Dominance of small phytoplankton species like Prochlorococcus sps., which contain high fractions of volatile and semivolatile organic compounds, coupled with increased stress due to global change, could result in increased phytoplankton cell mortality and lysis rates, thus, resulting in increased EDOC release rates to the water column and, potentially, to the atmosphere.

The published studies on DMS, VOCs and halogenated compounds, all of which contain carbon, show that phytoplankton release of volatile compounds, although not neglected, have been underestimated due to a focus on individual compounds, rather than bulk pools. Thus, the flux of volatile and semivolatile organic carbon from phytoplankton may be much greater than hitherto believed. Resolving the bulk cellular content of these compounds is a necessary step to assess the potential flux of phytoplankton-derived organic carbon to the surrounding waters, and the atmosphere.

\section{ACKNOWLEDGMENT}

This is a contribution to the "Malaspina 2010" COSOLIDER project funded by the Spanish Ministry of Science and Innovation (CSD2008-00077).

\section{REFERENCES}

Agardh, C. A. (1824). Systema Algarum. Lund: Literis Berlingianis Berling, 1-312. Agawin, N. S. R., Duarte, C. M., and Agustí, S. (2000). Nutrient and temperature control of the contribution of picoplankton to phytoplankton biomass and production. Limnol. Oceanogr. 45, 591-600. doi: 10.4319/1o.2000.45. 3.0591

Agustí, S., Duarte, C. M., Vaqué, D., Hein, M., Gasol, J. M., and Vidal, M. (2001). Food-web structure and elemental (C, N and P) fluxes in the eastern tropical North Atlantic. Deep Sea Res. II Top. Stud. Oceanogr. 48, 2295-2321. doi: 10.1016/S0967-0645(00)00179-X

Agustí, S., Satta, M. P., Mura, M. P., and Benavent, E. (1998). Dissolved esterase activity as a tracer of phytoplankton lysis: evidence of high phytoplankton lysis rates in the northwestern Mediterranean. Limnol. Oceanogr. 43, 1836-1849.

Bohlin, K. (1897). Zur Morphologie und Biologie einzelliger Algen. ofvers. VetenskAkad. Forh. Stockh. 54, 507-529.

Borthwick, K. A. J., Coakley, W. T., McDonnell, M., Nowotny, B. H., Benes, E., and Gröschl, M. (2005). Development of a novel compact sonicator for cell disruption. J. Microbiol. Methods 60, 207-216. doi: 10.1016/j.mimet. 2004.09

Bory de Saint-Vincent, J. B. M. (1822). Dictionaire Classique d'Histoire Naturelle. Vol. 17. Paris: Baudouin Freères.

Bravo-Linares, C., Mudge, S., and Loyola-Sepúlveda, R. (2010). Production of volatile organic compounds (VOCS) by temperate macroalage: the use of solid phase microextraction (SPME) coupled to GC-MS as method of analysis. J. Chilean Chem. Soc. 55, 227-232. doi: 10.4067/S0717-97072010000200018

Butcher, R. W. (1952). Contributions to our knowledge of the smaller marine algae. J. Mar. Biol. Assoc. 31, 175-191. doi: 10.1017/S0025315400003751

Butler, I. B., Schoonen, M. A. A., and Rickard, D. T. (1994). Removal of dissolved oxygen from water: a comparison of four common techniques. Talanta 41, 211-215. doi: 10.1016/0039-9140(94)80110-X

Chisholm, S. W., Frankel, S. L., Goericke, R., Olson, R. J., Palenik, B., Waterbury, J., et al. (1992). Prochlorococcus marinus nov. gen. nov. sp.: an oxyphototrophic 
marine prokaryote containing divinyl chlorophyll a and b. Arch. Microbiol. 157, 297-300. doi: 10.1007/BF00245165

Cleve, P. T. (1873). On Diatoms From the Arctic Sea. Vol. 1. Stockholm: PA Norstedt. Colomb, A., Yassaa, N., Williams, J., Peeken, I., and Lochte, K. (2008). Screening volatile organic compounds (VOCs) emissions from five marine phytoplankton species by head space gas chromatography/mass spectrometry (HS-GC/MS). J. Environ. Monit. 10, 325-330. doi: 10.1039/b715312k

Dachs, J., Calleja, M. L., Duarte, C. M., Del Vento, S., Turpin, B., Polidori, A., et al. (2005). High atmosphere-ocean exchange of organic carbon in the NE subtropical Atlantic. Geophys. Res. Lett. 32:L21807. doi: 10.1029/2005GL 023799

Dembitsky, V. M., Shkrob, I., and Lev, O. (2000). Occurrence of volatile nitrogencontaining compounds in nitrogen-fixing cyanobacterium aphanizomenon flos-aquae. J. Chem. Ecol. 26, 1359-1366. doi: 10.1023/A:1005423406140

Echeveste, P., Dachs, J., Berrojalbiz, N., and Agustí, S. (2010). Decrease in the abundance and viability of oceanic phytoplankton due to trace levels of organic pollutants. Chemosphere 81, 161-168. doi: 10.1016/j.chemosphere.2010.06.072

Fuhrman, J. A. (1999). Marine viruses and their biogeochemical and ecological effects. Nature 399, 541-548. doi: 10.1038/21119

Giese, B., Latumus, E., Adams, F. C., and Wiencke, C. (1999). Release of volatile iodinated $\mathrm{Cl}-\mathrm{C} 4$ hydrocarbons by marine macroalgae from various climate zones. Environ. Sci. Technol. 33, 2432-2439. doi: 10.1021/es980731n

Gschwend, P. M., Macfarlane, J. K., and Newman, K. A. (1985). Volatile halogenated organic compounds released to seawater from temperate marine macroalgae. Science 227, 1033-1035. doi: 10.1126/science.227.4690.1033

Guillard, R. R. L., and Hargraves, P. E. (1993). Stichochrysis immobilis is a diatom, not a chrysophyte. Phycologia 32, 234-236. doi: 10.2216/i0031-8884-32-3-234.1

Guillard, R. R. L., and Ryther, J. H. (1962). Studies of marine planktonic diatoms: I. cyclotella nana hustedt, and detonula confarvacea (cleve) Gran. Can. J. Microbiol. 8, 229-239. doi: 10.1139/m62-029

Hillebrand, H., Durselen, C. D., Kirschtel, D., Pollingher, U., and Zohary, T. (1999). Biovolume calculation for pelagic and benthic microalgae. J. Phycol. 35, 403-424. doi: 10.1046/j.1529-8817.1999.3520403.x

Jackson, G. A. (1980). Phytoplankton growth and zooplankton grazing in oligotrophic oceans. Nature 289, 439-441 doi: 10.1038/284439a0

Keller, M. D. (1988). Dimethyl sulfide production and marine phytoplankton: the importance of species composition and cell size. Biol. Oceanogr. 6, 375-382.

Kiørboe, T. (1993). "Turbulence, phytoplankton cell size, and the structure of pelagic food webs," in Advances in Marine Biology, ed D. W. Sims (London: Academic Press), 1-72.

Lagerheim, G. (1896). Über Phaeocystis pouchetii (Hariot) Lagerheim, eine Plankton-Flagellate. Övers. K. Vetensk-Akad. Förh. 4, 277-288.

Laturnus, F. (2001). Marine macroalgae in polar regions as natural sources for volatile organohalogens. Environ. Sci. Pollut. Res. 8, 103-108. doi: 10.1007/BF02987302

Llabrés, M., and Agustí, S. (2006). Picophytoplankton cell death induced by UV radiation: evidence for oceanic Atlantic communities. Limnol. Oceanogr. 51, 21-29. doi: 10.4319/lo.2006.51.1.0021

Marbà, N., Duarte, C. M., and Agustí, S. (2007). Allometric scaling of plant life history. Proc. Natl. Acad. Sci. U.S.A. 104, 15777. doi: 10.1073/pnas.0703476104

Marie, D., Simon, N., Guillou, L., Partensky, F., and Vaulot, D. (2000). "Flow cytometry analysis of marine picoplankton," in Living Color: Protocols in Flow Cytometry and Cell Sorting, eds R. A. Diamond and S. Demaggio (Berlin: Springer), 421-454.

Menden-Deuer, S., and Lessard, E. J. (2000). Carbon to volume relationships for dinoflagellates, diatoms, and other protist plankton. Limnol. Oceanogr. 45, 569-579. doi: 10.4319/lo.2000.45.3.0569

Moller, E. F. (2005). Sloppy feeding in marine copepods: prey-size-dependent production of dissolved organic carbon. J. Plankton Res. 27, 27-35. doi: 10.1093/plankt/fbh147

Montagnes, D. J., Berges, J. A., Harrison, P. J., and Taylor, F. J. R. (1994). Estimating carbon, nitrogen, protein, and chlorophyll a from volume in marine phytoplankton. Limnol. Oceanogr. 39, 1044-1060.

Moran, X. A. G., López -Urrutia, Á., Calvo-Díaz, A., and Li, W. K. W. (2010). Increasing importance of small phytoplankton in a warmer ocean. Global Change Biol. 16, 1137-1144. doi: 10.1111/j.1365-2486.2009.01960.x
Mullin, M. M., Sloan, P. R., and Epley, R. W. (1966). Relationship between carbon content, cell volume and area in phytoplankton. Limnol. Oceanogr. 11, 307-311.

Nageli, C. (1849). Gattungen einzelliger Algen, physiologisch und systematisch bearbeitet. Neue Denkschriften der Allg. Neuchâtel: Allgemeine schweizerische Gesellschaft für die gesammten Naturwissenschaften, 10, i-viii, 1-139, pls I-VIII.

Park, J. H., Goldstein, A. H., Timkovsky, J., Fares, S., Weber, R., Karlik, J., et al. (2013). Active atmosphere-ecosystem exchange of the vast majority of detected volatile organic compounds. Science 341, 643-647. doi: 10.1126/science. 1235053

Ruiz-Halpern, S., Calleja, M. L., Dachs, J., Del Vento, S., Pastor, M., Palmer, M., et al. (2014). Ocean-atmosphere exchange of organic carbon and $\mathrm{CO} 2$ surrounding the Antarctic Peninsula. Biogeosciences 11, 2755-2770. doi: 10.5194/bg-11-2755-2014

Ruiz-Halpern, S., Duarte, C. M., Tovar-Sanchez, A., Pastor, M., Horstkotte, B., Lasternas, S., et al. (2011). Antarctic krill as a major source of dissolved organic carbon to the Antarctic ecosystem. Limnol. Oceangr. 56, 521-528. doi: 10.4319/lo.2011.56.2.0521

Ruiz-Halpern, S., Sejr, M. K., Duarte, C. M., Krause-Jensen, D., Dalsgaard, T., Dachs, J., et al. (2010). Air-water exchange and vertical profiles of organic carbon in a subarctic fjord. Limnol. Oceanogr. 55, 1733-1740. doi: 10.4319/lo.2010.55.4.1733

Sinha, V., Williams, J., Meyerhöfer, M., Riebesell, U., Paulino, A. I., and Larsen, A. (2007). Air-sea fluxes of methanol, acetone, acetaldehyde, isoprene and DMS from a Norwegian fjord following a phytoplankton bloom in a mesocosm experiment. Atmos. Chem. Phys. 7, 739-755. doi: 10.5194/acp-7-739-2007

Spyres, G., Nimmo, M., Worsfold, P. J., Achterberg, E. P., and Miller, A. E. (2000). Determination of dissolved organic carbon in seawater using high temperature catalytic oxidation techniques. TrAC Trends Anal. Chem. 19, 498-506. doi: $10.1016 / \mathrm{S} 0165-9936(00) 00022-4$

Stein, F. R. V. (1883). "Der organismus der Infusionstiere III Abt," in II Halfte: Die Naturgesichte der Arthrodelen Flagellaten, ed W. Engelmann (Leipzig), 1-30.

Strathmann, R. R. (1967). Estimating the organic carbon content of phytoplankton from cell volume or plasma volume. Limnol. Oceanogr. 12, 411-418. doi: 10.4319/lo.1967.12.3.0411

Strom, S. L., Benner, R., Ziegler, S., and Dagg, M. J. (1997). Planktonic grazers are a potentially important source of marine dissolved organic carbon. Limnol. Oceanogr. 42, 1364-1374. doi: 10.4319/lo.1997.42.6.1364

Teodoresco, E. C. (1905). Organisation et développement du Dunaliella, nouveau genre de Volvocacée-Polyblepharidée. Beih z Bot Centralbl. Bd. XVIII, 215-232.

Van Alstyne, K. L. (2008). "Ecological and physiological roles of dimethylsulfoniopropionate and its products in marine macroalgae," in Algal Chemical Ecology, ed C. D. Amsler (Berlin: Springer), 173-188.

Verity, P. G., Robertson, C. Y., Tronzo, C. R., Andrews, M. G., Nelson, J. R., and Sieracki, M. E. (1992). Relationships between cell volume and the carbon and nitrogen content of marine photosynthetic nanoplankton. Limnol. Oceanogr. 37, 1434-1446. doi: 10.4319/lo.1992.37.7.1434

Williams, A. J. (2004). Organic trace gases in the atmosphere: an overview. Environ. Chem. 1, 125-136.

Conflict of Interest Statement: The authors declare that the research was conducted in the absence of any commercial or financial relationships that could be construed as a potential conflict of interest.

Received: 05 June 2014; accepted: 04 July 2014; published online: 24 July 2014. Citation: Ruiz-Halpern S, Echeveste P, Agustí S and Duarte CM (2014) Sizedependence of volatile and semi-volatile organic carbon content in phytoplankton cells. Front. Mar. Sci. 1:25. doi: 10.3389/fmars.2014.00025

This article was submitted to Marine Biogeochemistry, a section of the journal Frontiers in Marine Science.

Copyright (c) 2014 Ruiz-Halpern, Echeveste, Agustí and Duarte. This is an openaccess article distributed under the terms of the Creative Commons Attribution License (CC BY). The use, distribution or reproduction in other forums is permitted, provided the original author(s) or licensor are credited and that the original publication in this journal is cited, in accordance with accepted academic practice. No use, distribution or reproduction is permitted which does not comply with these terms. 